\title{
ПРЕЗИДЕНТ УКРАЇНИ ТА СУДОВА ВЛАДА: ОСНОВНІ ФОРМИ ТА ПРАВОВІ ЗАСОБИ ВЗАЕМОДІЇ
}

Постановка проблеми. У сучасній науці конституційного права України, в умовах проведення комплексної конституційної реформи заради підвищення авторитету судової гілки влади, одним із найбільш актуальних постає питання її взаємин з Президентом України. Як свідчить практика державно-правового життя багатьох країн світу, незалежне та неупереджене правосуддя $є$ передумовою існування демократичного суспільства, що керується верховенством права. Разом із тим Конституція України надає Президентові України досить суттєві повноваження, які стосуються безпосередньої організації органів судової гілки влади, а також дають змогу впливати на її діяльність. Будь-яка взаємодія вищих органів державної влади завжди відбувається у чітко визначених чинним законодавством формах та неможлива без застосування правових засобів, які сприяють досягненню взаємної рівноваги, а також гарантій забезпечення функціонування системи стримувань $\mathrm{i}$ противаг між ними, про що і йтиметься далі.

Аналіз останніх досліджень і публікацій. Визначення місця Президента України у системі поділу влади, дослідження окремих аспектів його взаємодії з іншими вищими органами державної влади, а також встановлення форм і правових засобів забезпечення функціонування системи стримувань і противаг знайшли своє відображення в працях С. Батова, Л. Летнянчина, М. Марченка, А. Мішина, І. Процюка, С. Серьогіної, Ю. Тодики, В. Чіркіна та багатьох інших. Однак слід відзначити, що досі не здійснений комплексний аналіз безпосередньої взаємодії Президента України із судовою гілкою влади, тому ґрунтовне дослідження цього питання є доволі актуальним натепер.

Мета статті - проаналізувати основні форми та правові засоби належної взаємодії Президента України з судовою гілкою влади, а також визначити гарантії забезпечення ефективного функціонування системи стримувань та противаг між ними.

Виклад основного матеріалу дослідження. Відповідно до норм чинного Основного Закону України Президент України посідає одне з провідних місць у системі вищих органів державної влади, а також відіграє неабияку роль у формуванні політичного курсу нашої держави. При цьому структурно він не входить до встановленої ст. 6 Конституції України тріади влади. Згідно з положеннями ст. 102 Конституції України, Президент є главою держави і виступає від її імені, а також постає гарантом державного суверенітету, територіальної цілісності України, додержання Конституції України, прав і свобод людини і громадянина [1, с. 33]. Ми погоджуємось з думками М. Цвіка, І. Процюка, С. Серьогіної стосовно того, що шляхом визнання Президента України гарантом підкреслюється його центральне місце в системі державних органів, покликаних забезпечувати реалізацію прав і свобод людини та громадянина [2, с. 20], а також його особлива, провідна роль та вищий авторитет [3, с. 54]. Одночасно з цим статус гаранта жодною мірою не означає безмежності його компетенції і права на втручання в діяльність інших органів 
державної влади [2, с. 21], оскільки у будь-якому разі Президент України має дотримуватися вимог ч. 2 ст. 19 Конституції України та діяти лише на підставі, в межах повноважень та у спосіб, що передбачені Конституцією та законами України.

Як слушно зауважує А. Мішин, Президент здійснює свої повноваження в рамках функціонуючої системи стримувань і противаг між трьома гілками влади, які перебувають подеколи в дуже складних і не завжди збалансованих відносинах $[4$, c. 180]. На нашу думку, саме глава держави фактично виступає тим арбітром, стримуючим фактором, який покликаний координувати діяльність усіх вищих органів державної влади, не входячи безпосередньо до жодної з її гілок. Разом із тим функціонально він пов'язаний обов'язком співробітництва з усіма вищими органами державної влади і є одним із вагомих елементів системи стримувань і противаг. Погоджуючись 3 думкою В. Чіркіна, відзначимо, що необхідність такої взаємодії також випливає із загального напряму державної політики, що не виключає відмінностей у способах, методах здійснення державної влади тими чи іншими державними органами і не скасовує можливих конфліктів гілок влади, їх органів між собою [5, с. 70]. Не слід оминати увагою також той факт, що реальна влада глави держави залежить не тільки від обсягу належних йому конституційних повноважень, а й безпосередньо від форми правління, характеру політичного режиму та співвідношення політичних сил у країні в той чи інший період часу, i, звичайно, від особистих якостей особи, яка обіймає цю посаду [6, с. 592].

3 іншого боку, не менш важливим елементом системи стримувань і противаг виступає судова гілка влади, яка насамперед покликана не тільки врівноважувати обидві інші - законодавчу і виконавчу, а й обов'язково спрямовувати їх діяльність та діяльність Президента України, інших органів державної влади, посадових осіб у правове поле. Саме про це також зауважує Р. Гринюк, вважаючи здійснення судової влади особливою державною функцією налагодження узгодженої поведінки суб'єктів у рамках законності [7, с. 33].

Головна особливість судової влади, про яку говорить у книзі «Про дух законів» Ш. Монтеск'є, полягає в її̈ обов'язку точного і неухильного застосування букви і духу закону, але в умовах найсуворішого дотримання процесуальних форм. 3 трьох гілок влади судова, у відомому сенсі, як би зовсім не влада - це більш гарантія, ніж політична влада [8, с. 23]. Справді, вже сама по собі задекларована на конституційному рівні, а в подальшому впроваджена в життя судова влада в особі суддів, гарантує вирішення можливих конфліктів, юридичних спорів виключно в правовому полі з позицій верховенства права, справедливості і законності.

$\mathrm{y}$ демократичних, правових суспільствах саме на судові органи та установи, які виступають у ролі захисника особистих свобод громадян, покладається завдання щодо контролю за виконанням вимог чинного законодавства і гарантування дотримання прав кожного. А всі без винятку органи державної влади, вищі посадові особи стосовно судової гілки влади та її рішень не мають імунітету і не користуються привілеями. Суди всіх рівнів постійно виконують дві найважливіші функції: правозахисну і правовідновлюючу. Їх не можуть виконувати в повному обсязі інші установи, оскільки рішення суду набуває обов'язкової сили для всіх державних органів і посадових осіб, а в разі потреби забезпечується примусом. 
Досить важливою є також функція суду, спрямована на визначення внутрішніх та зовнішньої правових меж функціонування вищих органів державної влади, в тому числі Президента України. У діяльності таких органів влади значне місце посідає політична доцільність, а також владу істотно послаблює постійно наявна загроза конфлікту між ними. Повернути основи державної влади до внутрішньо збалансованого становища найкраще за всіх здатен суд через те, що він повністю «пов'язаний» правом, має чітку процедуру з відповідними обмеженнями і спроможністю суворого дотримання заздалегідь визначеного предмета спору [7, с. 35].

Звертаючись до питання, яким чином взаємодіють судова гілка влади з Президентом України, слід сказати, що основні форми, правові засоби взаємодії та їх гарантії визначаються Конституцією України, а також положеннями Закону України «Про судоустрій і статус суддів». Суттєві зміни у взаєминах Президента України з органами та установами судової гілки влади відбулись після схвалення Верховною Радою України 02 червня 2016 року законопроекту «Про внесення змін до Конституції України (щодо правосуддя)», який, до речі, було подано на розгляд парламенту Президентом України як суб'єктом права законодавчої ініціативи з метою забезпечення незалежності судової влади, оптимізації системи судоустрою, забезпечення ефективної роботи органів судової влади. 3 прийняттям вищевказаного законопроекту ознаменовано початок проведення конституційної судової реформи, відповідно до якої докорінно змінились порядок створення, реорганізації, ліквідації судів, окремих органів судової влади, деякі кадрові функції (призначення суддів, членів Вищої ради правосуддя) тощо. На думку багатьох науковців, запроваджені зміни до Основного Закону України, які залишили за Президентом України виключно «церемоніальну» роль у порядку формування та функціонуванні судової гілки влади [9], повністю відокремивши її від політичного впливу з цього боку, є доволі позитивними. Однак, на нашу думку, на практиці не завжди можна цілком відсторонитись від політики: одним із проявів такого впливу можна вважати здійснення судовою владою своєї діяльності суто в рамках чинних законодавчих актів, норми яких у будь-якому разі приймаються політичним органом державної влади - Верховною Радою України.

Одним з основних напрямів або форм взаємодії Президента України з судовою гілкою влади ми вважаємо порядок формування найголовніших органів судової влади - судів. Відповідно до положень ст. 125 Конституції України, ч. 2 ст. 19 Закону України «Про судоустрій і статус суддів» нині утворення, реорганізація і ліквідація суду буде відбуватись відповідно до закону, проект якого вносить до Верховної Ради України Президент України після консультацій з Вищою радою правосуддя [1, с. 44; 10]. Зауважимо, що від розгалуженості системи судів, визначення їх кількості на певній території прямо залежить гарантування доступу до правосуддя будь-якої особи задля відновлення чи захисту своїх прав та законних інтересів. Звичайно, що попередні консультації з Вищою радою правосуддя однозначно дадуть відповідь на питання: яку кількість судів потребує той чи інший регіон нашої держави з урахуванням кількості населення, статистики щодо розгляду різних категорій справ на відповідній території тощо. Однак останне слово у будь-якому разі залишається за Президентом України, а прямого обов'язку враховувати відповідні пропозиції чи зауваження з боку Вищої ради правосуддя у 
майбутньому законопроекті чинним законодавством наразі не визначено. Також доопрацювання цього законопроекту під час його попереднього розгляду Верховною Радою України та внесення конструктивних правок до нього не забороняє Президенту України скористатись своїм правом, визначеним п. 30 ч. 1 ст. 106 Конституції України та накласти вето на відповідний закон. У цьому сенсі питання щодо створення, реорганізації чи ліквідації судів, на нашу думку, цілком ймовірно може перейти з правового поля в суто політичне.

Якщо розглядати визначений порядок створення, реорганізації чи ліквідації судів з іншої позиції, то слід зауважити, що чітко визначений статтею 125 Конституції України суб'єкт права законодавчої ініціативи щодо внесення законопроекту з вищезазначених питань на розгляд Верховної Ради України є потужною гарантією системи стримувань і противаг щодо демократичного, неупередженого та незалежного порядку становлення судової гілки влади та мінімізує вплив політичної еліти (народних депутатів України, членів Кабінету Міністрів України) на цей процес.

Слід згадати, що відповідно до п.п. 6 п. 16-1 Перехідних положень Конституції України до впровадження нового адміністративно-територіального устрою України відповідно до змін до Конституції України щодо децентралізації влади, але не довше ніж до 31 грудня 2017 року, утворення, реорганізацію та ліквідацію судів здійснював Президент України на підставі та у порядку, які визначені законом. Саме тому наприкінці 2017 року шляхом видання указів № 449/2017, № 450/2017, № 451/2017, № 452/2017, № 453/2017, № 454/2017, № 455/2017 від 29 грудня 2017 року Президентом України фактично в одноосібному порядку було створено нову систему місцевих окружних судів та апеляційних судів в апеляційних округах, здебільшого шляхом їх об'єднання між собою із застосуванням процедури реорганізації або ліквідації. Такий порядок створення нових окружних судів, для прикладу у м. Харкові, показав практику неврахування вагомих пропозицій Державної судової адміністрації України, Вищої ради правосуддя під час видання указу Президентом України про недоцільність об'єднання досить великих за кількістю штатних посад, кількістю та складністю розглядуваних справ Дзержинського та Київського районних судів м. Харкова в один місцевий окружний суд, оскільки це може призвести до серйозних ускладнень у роботі апарату суду та зниження якості здійснюваного правосуддя суддями. I подібних прикладів безліч. Дотепер процедура формування окружних судів по Україні ще не завершена в повному обсязі, відбувається перехідний етап у становленні нових судів, який має завершитись у 2019 році.

Окремої уваги заслуговують кадрові повноваження Президента України в сфері судової гілки влади, адже цілком зрозуміло, що саме від судді, рівня його професійності та компетентності залежить якість здійснення судочинства, а також певною мірою своєчасність та оперативність розгляду справ. Зазначимо, що право глави держави призначати суддів є однією із форм його взаємодії із судовою владою, яке $€$ не в усіх державах, може належати не до всіх суддів і часто має формальний характер підписання відповідного указу [5, с. 214]. С. Зарудний слушно зауважував, що мета судочинства полягає в заповненні судових місць таким чином, щоб судові рішення користувалися загальною довірою, а довіра необхідна як найтвердіша опора, як основна умова загального спокою в державі [8, с. 8]. 
Натепер відповідно до вимог ч. 1 ст. 128 Конституції України призначення на посаду судді здійснюється Президентом України за поданням Вищої ради правосуддя в порядку, встановленому законом [1, с. 45]. Згідно з положеннями ч. 2 ст. 57 Закону України «Про судоустрій і статус суддів», суддя складає присягу під час урочистої церемонії у присутності Президента України, а до участі в церемонії запрошуються Голова Верховного Суду, Голова Ради суддів України, Голова Вищої ради правосуддя та Голова Вищої кваліфікаційної комісії суддів України [10]. Наведене вище дає підстави погодитись з думкою О. Зозулі про те, що зосередження у Президента України кадрових повноважень стосовно призначення суддів на посади зумовлене його правовим статусом глави держави, який формально не входить до жодної з гілок державної влади та одночасно є найвищою посадовою особою, завдяки чому забезпечується внутрішня узгодженість державного апарату [11, с. 46].

Сама процедура призначення на посаду судді детально регламентована в положеннях статей Закону України «Про судоустрій і статус суддів». На нашу думку, окремо слід проаналізувати положення ч. 1,2 ст. 80 вищевказаного закону, відповідно до яких Президент України призначає на посаду суддю шляхом видання відповідного указу в термін не пізніше тридцяти днів із дня отримання відповідного подання Вищої ради правосуддя, без перевірки додержання встановлених законом вимог до кандидатів на посаду судді та порядку проведення добору чи кваліфікаційного оцінювання кандидатів. Будь-які звернення щодо кандидата на посаду судді не перешкоджають його призначенню на посаду, а викладені в таких зверненнях факти можуть бути підставою для порушення Президентом України перед компетентними органами питання про проведення в установленому законом порядку перевірки цих фактів [10]. 3 вищевказаних положень Конституції України та Закону України «Про судоустрій і статус суддів» фактично випливає обов'язок Президента України призначити подану кандидатуру на посаду судді, оскільки подання Вищої ради правосуддя як таке вже само по собі гарантує належний порядок проведеної процедури перевірки та оцінювання визначеної особи кандидата відповідно до вимог чинного законодавства. Як було зазначено в пояснювальній записці до законопроекту «Про внесення змін до Конституції України (щодо правосуддя)", здійснення призначення на посаду судді Президентом України за поданням Вищої ради правосуддя забезпечить виключно «церемоніальну» роль глави держави у цьому процесі [12], а також максимально відокремить процедуру призначення судді на посаду від політичного впливу.

Також слід вказати, що натепер права зміщувати суддів з посад глава держави не має. Повноваження з ухвалення таких рішень належать, згідно з нормами чинного законодавства, виключно Вищій раді правосуддя, яка має ретельно перевірити наявність підстав для звільнення або припинення діяльності судді, що також виступає, на нашу думку, однією з гарантій не тільки незалежності, неупередженості судді, а й системи стримувань і противаг між судовою гілкою влади та іншими органами державної влади в цілому. Фактично суддя під час здійснення правосуддя, під час прийняття рішення у конкретно визначеній справі захищений не тільки від впливу на його позицію з приводу обставин справи з боку інших вищих органів державної влади, а й від можливого відсторонення з посади за винесення «неспра- 
ведливого» (у будь-якому разі для однієї зі сторін) рішення, особливо в тих ситуаціях, де одним з учасників процесу може виступати той вищий орган державної влади, який бере участь у процедурі призначення, звільнення судді або припинення його діяльності. А додатковою гарантією щодо незалежності, неупередженості i професійності майбутнього судді виступає право Президента України щодо порушення перед компетентними органами питання про проведення в установленому законом порядку перевірки "сумнівних», на його думку, фактів стосовно особи кандидата на посаду судді (ст. 80 Закону України «Про судоустрій і статус суддів»).

Встановлення та забезпечення у ст. 128 Конституції України, після внесення відповідних змін, стандарту незмінюваності суддів, тобто обіймання суддею посади безстроково з моменту призначення, як слушно зауважує Л. Летнянчин, також виступає гарантією системи стримувань і противаг у взаєминах судової влади з іншими гілками та Президентом України [9, с. 195]. Фактично однією з вимог конституційної судової реформи було саме скасування інституту призначення судді на посаду «вперше», без можливості його переобрання через п'ять років на посаду безстроково, після проходження так званого «випробувального терміну». Це виступає реальним запобіжником зменшення втручання інших гілок державної влади та Президента України у формування кадрового складу судової гілки влади.

Необхідною формою взаємодії Президента України з судовою гілкою влади, у визначених Конституцією України та чинним законодавством випадках, виступає участь Верховного Суду у процедурі дострокового припинення повноважень глави держави. Положеннями ст. 110, 111 Конституції України, ст. 36, 46 Закону України «Про судоустрій і статус суддів» передбачено, що саме Верховний Суд надає висновок про наявність чи відсутність у діяннях, в яких звинувачується Президент України, ознак державної зради або іншого злочину та вносить за зверненням Верховної Ради України письмове подання про неспроможність виконання Президентом України своїх повноважень за станом здоров'я [1, с. 38-39; 10]. Необхідність отримання висновку чи подання Верховного Суду підтверджує та гарантує те, що процедура припинення повноважень глави держави з визначених підстав (п. 2, 3 ч. 1 ст. 108 Конституції України) була проведена незалежно, неупереджено та без відхилень від порядку, чітко визначеного законодавчими актами, що, на нашу думку, може вважатись додатковою гарантією системи стримувань та противаг у взаєминах між главою держави та судовою гілкою влади.

Незважаючи на закріплення в Конституції України принципу поділу влади та виключної компетенції судової гілки щодо здійснення правосуддя, глава держави традиційно володіє і деякими «судовими» повноваженнями, до яких можна віднести здійснення права помилування (п. 27 ч. 1 ст. 106 Конституції України). Це право Президента України виступає ще однією формою безпосередньої взаємодії з судовою гілкою влади. Адже досить цікавим видається той факт, що глава держави своїм владним рішенням може змінити вирок суду стосовно конкретно визначеної особи засудженого, при цьому такий вирок уже набрав законної сили або перебуває на стадії перегляду. О. Волощук слушно зауважує, що таке право є важливим елементом компетенції Президента України щодо осіб, засуджених судами за скоєння злочину [13, с. 48], та гарантує кожному засудженому можливість звернутися з проханням про помилування 
до глави держави. Право помилування і пом'якшення покарань йде з тих часів, коли монарх був вищим суддею [5, с. 215]. Натепер владне рішення Президента України під час вирішення питання щодо помилування не виноситься просто так, а попередньо має бути опрацьоване в багатьох інстанціях (зокрема, Департаментом з питань помилування Адміністрації Президента України, Комісією при Президентові України у питаннях помилування тощо), в тому числі після отримання довідки від адміністрації установи виконання покарань про поведінку засудженого.

Висновки. Підсумовуючи вищевикладене, зазначимо, що після впровадження судової конституційної реформи у 2016 році, внесення відповідних змін до Конституції України та Закону України «Про судоустрій і статус суддів» докорінно змінився порядок взаємодії між Президентом України та судовою гілкою влади. Однак це зовсім не виключило політичних, правових суперечок, які у будь-якому разі можуть виникати між вищими органами державної влади та змушують час від часу переглядати наявні форми і засоби стабілізації системи конституційного регулювання політико-правових відносин і спонукають до їх удосконалення.

Судова гілка влади в демократичній державі виступає головним інструментом, за допомогою якого право впливає на суспільні відносини в конфліктних випадках, тому має бути деполітизованою не тільки на папері, а й в дії. Це сприяє більшій довірі до неї з боку суспільства, є чинником забезпечення її незалежності, об’єктивності, безсторонності та неупередженості, а як наслідок - надає можливість належним чином виконувати відведену їй роль у системі розподілу влади. А Президент України, своєю чергою, маючи статус гаранта державного суверенітету, територіальної цілісності України, додержання Конституції України, прав і свобод людини та громадянина, в одноосібному порядку не може вирішити всі проблемні питання взаємодії вищих органів державної влади між собою, оскільки рівновага між ними досягається лише в тому разі, коли реально функціонує вся система стримувань і противаг у сукупності.

\section{Jimepamypa}

1. Конституція України: станом на 25 серп. 2017 р.: відп. офіц. тексту. Харків : ППФ «Поліграфiст», 2017. $64 \mathrm{c}$.

2. Серьогіна С.Г. Президент України у механізмі забезпечення прав і свобод людини і громадянина. Права людини і правова держава (до 50-ї річниці Загальної декларацї̈ прав людини) : тези доповідей та наукових повідомлень наук. конф. проф.-викл. складу (м. Харків, 10-11 грудня 1998 р.). Харків, 1998. С. 20-22.

3. Цвік М., Процюк І. Про державно-правову природу влади Президента України в системі розподілу влад. Вісник Академії правових наук України. 1999. № 1(16). С. 51-61.

4. Мишин А.А. Государственное право США : монография. Москва : Наука, 1976. 205 с.

5. Чиркин В.Е. Глава государства. Сравнительно-правовое исследование : монография. Москва : Норма: Инфра-М. 2010. 240 с.

6. Чиркин В.Е., Ковлер А.И., Юдин Ю.А. Сравнительное конституционное право : монография. Москва : Издательская фирма «Манускрипт», 1996. 729 с.

7. Гринюк Р.Ф. Судова влада як фундаментальний чинник становлення правової держави в Україні. Бюлетень Міністерства юстииї України. 2005. № 2. С. 27-36.

8. Батова С.А. Судебная система России : учебное пособие. Москва : Дело, 2000. 336 с.

9. Летнянчин Л.І. Конституційна судова реформа: проблеми та перспективи. Вісник Національної академії правових наук України. 2016. № 3 (86). С. 194-203. 
10. Про судоустрій і статус суддів : Закон України від 02.06.2016 p. № 1402-VIII. Дата оновлення: 05.08.2018. URL: http://zakon.rada.gov.ua/laws/show/1402-19/print.

11. Зозуля O.I. Конституційне регулювання правового статусу Президента України як глави держави. Університетські наукові записки. 2009. №1. С. 42-48.

12. Про внесення змін до Конституції України (щодо правосуддя) : проект Закону від 25.11.2015 p. № 3524. URL: http://w1.c1.rada.gov.ua/pls/zweb2/webproc4_1?pf3511=57209.

13. Волощук О.Т. Повноваження Президента України щодо судової влади. Науковий вісник Чернівещького університету. 2011. Вип. № 578. С. 46-50.

\section{Анотація}

Малишкіна Н. О. Президент України та судова влада: основні форми та правові засоби взаємодії. Стаття.

У статті визначено місце Президента України у системі вищих органів державної влади в Україні. Проаналізовані різні аспекти взаємодії судової гілки влади з Президентом України. Зроблено висновок, що на практиці важливий не лише розподіл повноважень вищих органів державної влади задля досягнення цілей, визначених у Конституції України, а й їх безпосередня взаємодія між собою, яка з необхідністю відбувається у чітко визначених правових формах із застосуванням відповідних правових засобів. Наявність будь-якого політичного впливу з боку Президента України та інших вищих органів державної влади, недотримання основних принципів права в діяльності судової гілки влади веде до несправедливого розгляду виникаючих конфліктів. Реальним запобіжником таких ситуацій виступають чинні гарантії функціонування судової гілки влади у взаєминах насамперед 3 Президентом України та іншими вищими органами державної влади в Україні.

Ключові слова: поділ влади, система стримувань і противаг, гарантії системи стримувань і противаг, взаємодія вищих органів влади, Президент України, судова влада, форми взаємодії, правові засоби взаємодії.

\section{Аннотация}

Малышкина Н. О. Президент Украины и судебная власть: основные формы и правовые средства взаимодействия. - Статья.

В статье определено место Президента Украины в системе высших органов государственной власти в Украине. Проанализированы различные аспекты взаимодействия судебной ветви власти с Президентом Украины. Сделан вывод, что на практике важно не только распределение полномочий высших органов государственной власти для достижения целей, определённых в Конституции Украины, но и их непосредственное взаимодействие между собой, которое с необходимостью происходит в чётко определенных правовых формах с применением соответствующих правовых средств. Наличие любого политического влияния со стороны Президента Украины и других высших органов государственной власти, несоблюдение основных принципов права в деятельности судебной ветви власти ведет к несправедливому рассмотрению возникающих конфликтов. Предотвратить подобную ситуацию помогают действующие гарантии функционирования судебной ветви власти во взаимоотношениях в первую очередь с Президентом Украины и другими высшими органами государственной власти в Украине.

Ключевые слова: разделение властей, система сдержек и противовесов, гарантии системы сдержек и противовесов, взаимодействие высших органов власти, Президент Украины, судебная власть, формы взаимодействия, правовые средства взаимодействия.

\section{Summary}

Malyshkina N.O. President of Ukraine and Judiciary: the main forms and legal means of interaction.Article.

The place of the President of Ukraine in the system of supreme bodies of state power in Ukraine is determined. Different aspects of interaction of the judicial branch with the President of Ukraine are analyzed. It is concluded that in practice not only the distribution of powers of the higher state authorities is important for the achievement of the goals defined in the Constitution of Ukraine, but also their direct interaction with each other, which necessarily takes place in clearly defined legal forms with the use of appropriate legal means. The existence of any political influence on the part of the President of Ukraine and other supreme bodies of state power, violation of the basic principles of law in the activity of the judicial branch of government leads to unfair treatment of emerging conflicts. The actual safeguard of such situations is the existing safeguards for the functioning of the judicial branch in the relations, first of all, with the President of Ukraine and other senior bodies of state power in Ukraine.

Key words: separation of powers, system of checks and balances, guarantees of the system of checks and balances, interaction of higher authorities, President of Ukraine, judiciary, forms of interaction, legal means of interaction. 